\title{
Sequence variation in four mitochondrial genes of the salmon louse Lepeophtheirus salmonis
}

\author{
Kjersti Tjensvoll ${ }^{1, *}$, Kevin A. Glover ${ }^{2}$, Are Nylund ${ }^{1}$ \\ ${ }^{1}$ Department of Biology, University of Bergen, 5020 Bergen, Norway \\ ${ }^{2}$ Population Genetics Research Group, Institute of Marine Research, PO Box 1870 Nordnes, 5817 Bergen, Norway
}

\begin{abstract}
A total of 210 Lepeophtheirus salmonis collected from 7 locations (Scotland, Russia, Canada, Japan and 3 locations in Norway), were screened for sequence variation in 4 mitochondrial genes; ATPase subunit $6(A 6)$, Cytochrome $b$ oxidase subunit I (COI), Cytochrome $b(C y t b)$ and 16S rRNA. A high level of intraspecific variation was observed within all genes. The majority of polymorphisms were present in single individuals only, which resulted in a high number of private haplotypes within each gene. Little evidence of genetic differentiation was observed among the 3 Norwegian locations or between $L$. salmonis samples from Norway, Scotland and Russia. Pairwise $\mathrm{F}_{\mathrm{ST}}$ values indicated that a weak degree of sub-division between L. salmonis sampled in Canada and the Northeast Atlantic might, however, exist. All samples collected in the Atlantic were highly different from the Japanese sample. It is suggested that the lack of genetic differentiation among lice samples from the North Atlantic is a result of extensive gene flow mediated by passive transport of $L$. salmonis larvae, and the migratory pattern of its salmonid hosts.
\end{abstract}

KEY WORDS: Lepeophtheirus salmonis $\cdot A 6 \cdot C O I \cdot 16 \mathrm{~S}$ rRNA $\cdot C y t b \cdot$ Sequence variation Population genetics $\cdot$ Sea lice

Resale or republication not permitted without written consent of the publisher

\section{INTRODUCTION}

Lepeophtheirus salmonis is an ectoparasitic marine copepod of salmonid fish in the northern hemisphere, causing large economic losses to the Atlantic salmon farming industry (Kabata 1979, Mustafa et al. 2001). The pathology is a result of feeding on mucus, epidermis and blood resulting in severe skin damage (White 1940, Brandal et al. 1976, Wootten et al. 1977, 1982, Kabata 1979). Damage of the skin may further lead to osmoregulatory breakdown and secondary infections (Wootten et al. 1982, Nylund et al. 1993). In areas with salmonid aquaculture, the salmon louse may also constitute a serious threat to wild populations of both Atlantic salmon Salmo salar L., and sea trout Salmo trutta L. (Tully et al. 1993, Birkeland 1996, Johnson et al. 1996, Holst \& Jackobsen 1998, Bjørn et al. 2001, Bjørn \& Finstad 2002, Butler 2002). Despite this, relatively little is known about the population genetic structure and the dispersal of $L$. salmonis in the North Atlantic Ocean.
The life cycle of Lepeophtheirus salmonis includes 2 planktonic larvae stages (nauplius I and II) and one infective stage (a free-swimming copepodid), in addition to the parasitic stages (Kabata 1979, Johnson \& Albright 1991b, Schram 1993). Development from nauplius I to the infectious copepodid can last up to $13 \mathrm{~d}$ at $10^{\circ} \mathrm{C}$ (Johnson \& Albright 1991a), resulting in an extremely high spreading potential through passive transport of the planktonic larvae. However, since it is difficult to track invertebrate larvae in the marine environment, little information exists about drift distances of $L$. salmonis larvae due to wind speed, tidal flow and ocean current (Costelloe et al. 1996, Costelloe et al. 1998, Asplin et al. 2002, McKibben \& Hay 2004). In addition to passive transport by water currents, the parasitic stages of the lice may be transported further by its host's migratory pattern. Transmission of $L$. salmonis at salmon feeding grounds in the North Atlantic Ocean (Norwegian Sea) is conceivable, since all parasitic stages have been found on wild salmon in 
this area (Berland 1993, Holst et al. 1993, Jacobsen \& Gaard 1997).

Several authors have investigated the population genetic structure of Lepeophtheirus salmonis (Isdal et al. 1997, Todd et al. 1997, 2004, Nolan et al. 2000, Tully \& Nolan 2002, Dixon et al. 2004). Studies of allozymes and random amplification of polymorphic DNA (RAPD) have indicated that different L. salmonis populations may exist in both Norway (Isdal et al. 1997) and Scotland (Todd et al. 1997, Dixon et al. 2004). Genetic differences have also been found between $L$. salmonis sampled in Norway, Scotland and Ireland (Nolan et al. 2000). However, in a recent study using 6 microsatellite markers, no genetic differentiation was found between samples of L. salmonis collected on wild and farmed salmonids in Scotland, nor between L. Salmonis collected on salmonids from Scotland, Norway and Canada (Todd et al. 2004).

Mitochondrial DNA (mtDNA) displays a high mutation rate, accumulating substitutions up to 10 times faster than nuclear genes (Shearer et al. 2002). Combined with the fact that these genes are maternally inherited, reducing the effective population size and increasing opportunity for genetic drift, this makes these genes particularly suitable for population genetic studies. Consequently, mitochondrial genes have been extensively used in studies of population structure, patterns of gene flow and phylogenetic relationships (e.g. Hale \& Singh 1987, Garcia-Machado et al. 1999, Saito et al. 2000, Schwenk et al. 2000, Umetsu et al. 2002, Gantenbein \& Largiader 2003). Cytochrome $c$ oxidase subunit I (COI), 16S rRNA, ATPase subunit $6(A 6)$ and Cytochrome $b(C y t b)$ are among the mitochondrial genes that are highly informative for population genetic studies in other crustaceans and arthropods (e.g. Marshall \& Baker 1999, Lee 2000, McGlashan \& Hughes 2000, Jarman et al. 2002, Hurwood et al. 2003).

As there is disagreement between published data sets with respect to the extent of population genetic structure within Lepeophtheirus salmonis, it was the aim of this study to utilise genetic variation within 4 mitochondrial genes to provide further insight into the population genetic structure of this species.

\section{MATERIALS AND METHODS}

Salmon lice samples. A total of 30 Lepeophtheirus salmonis were collected from each of the following locations: Norway (Finmark, July 2000; Sogn og Fjordane, July 2002; Øst-Agder, May/September 2002); Scotland (Broadford, Skye, July 2002); Canada (New Brunswick, Grand Manan, December 2002); Russia (Pechora, Nenets Avtonomij Vokrug, August/Octo- ber, 2000); and Japan (Ishikari, September 1995). Exact coordinates for L. salmonis sampling sites are not available. Generally, 15 males and 15 females were collected from each location, except from Russia and Japan where 30 females were collected. All lice were pre-adults or adults. L. salmonis from Øst-Agder were collected from wild sea trout Salmo trutta. Lice from Japan were collected from wild chum salmon Oncorhynchus keta, while the Russian lice were collected from wild Atlantic salmon Salmo salar. All other samples were collected from farmed Atlantic salmon.

Genomic DNA extraction. The gut of adult salmon lice (stored in $70 \%$ ethanol) was removed before DNA was extracted using the DNeasy DNA Tissue kit (Qiagen) as recommended by the manufacturer. RNase treatment was included to improve DNA quality. Elution was performed twice in $50 \mathrm{ml} 10 \mathrm{mM}$ Tris- $\mathrm{HCl}$, $\mathrm{pH}$ 8.5 to increase the overall DNA yield, and the DNA was stored at $-20^{\circ} \mathrm{C}$.

Amplification. The complete gene sequences of COI, Cyt b, A6 and 16S rRNA were amplified from 180 Lepeophtheirus salmonis using primers constructed from the complete mitochondrial sequence obtained by Tjensvoll et al. (2005) (Table 1). The PCR mixture $(50 \mu \mathrm{l})$ contained $1 \times$ PCR buffer with $1.5 \mathrm{mM}$ $\mathrm{MgCl}_{2}$ (Amersham Pharmacia Biotech), $25 \mathrm{mM}$ of each dNTP (Promega), $0.2 \mu \mathrm{M}$ of each primer (Invitrogen), 1U Taq DNA polymerase (Amersham Pharmacia Biotech) and $300 \mathrm{ng}$ DNA. Amplification was performed in a GeneAmp PCR System 9700 (Applied Biosystems) at $95^{\circ} \mathrm{C}$ for $5 \mathrm{~min} ; 35$ cycles of $94^{\circ} \mathrm{C}$ for $30 \mathrm{~s}, 48^{\circ} \mathrm{C}(A 6$ and $C y t b)$ and $52^{\circ} \mathrm{C}(16 \mathrm{~S}$ rRNA and $\mathrm{COI}$ ) for $30 \mathrm{~s}, 72^{\circ} \mathrm{C}$ for $1 \mathrm{~min} ; 72^{\circ} \mathrm{C}$ for $7 \min ; 4^{\circ} \mathrm{C}$.

Sequencing and sequence analysis. PCR products were purified with QIAquick PCR purification kit (Qiagen) as described by the manufacturer. Sequencing was then performed in one direction with ABI PRISM BigDye (v.2) terminator chemistry according to Applied Biosystems (ABI). All sequences were identified by BLAST, which resulted in significant hits with homologous sequences from other caligids and arthropod species. The sequences were imported into the Vector NTI Suite 7.0 program (InforMax) for editing, followed by alignment using default settings. Sequences obtained in this study were submitted to (GenBank. Accession numbers are: (Cyt b) AY602223-AY602402, (A6) AY602407-AY602586, (COI) AY602587-AY602766 and (16S rRNA) AY602770-AY602949.

The protein coding genes COI, Cyt $b$ and $A 6$ were translated in the Vector NTI Suite 7.0 program, using the mitochondrial genetic code, before conserved motifs and domains were identified by SMART and Swiss-Prot by comparing the Lepeophtheirus salmonis sequences to the structures from Drosophila yakuba (COI: P00400, Cyt b: P07704 and A6: P00851). 
Table 1. Lepeophtheirus salmonis. Primers for amplification of the mitochondrial genes A6, Cyt b, 16S rRNA and COI

\begin{tabular}{|c|c|c|c|}
\hline Gene & Forward primer $\left(5^{\prime} \rightarrow 3^{\prime}\right)$ & Reverse primer $\left(5^{\prime} \rightarrow 3^{\prime}\right)$ & No. of base pairs \\
\hline$A 6$ & CCTAGGTCGAAACTAGGACA & CCTGATAAGCAAGTGCCC & 1193 \\
\hline COI & GAAGGCGGGTTACTTACC & CGATAAGACCCTAAGACC & 2019 \\
\hline 16S rRNA & GTCCTCCGTATAACCATTC & GCACTTTCTTATTCAGAACT & 1388 \\
\hline Cyt b & ATGTTAGGGAGACTCTTC & GAGAGATTTCTACAGCGTTTTTATC & 1108 \\
\hline $3^{\prime}$-end of $C y t b^{\mathrm{a}}$ & GAGCCTACAACTCAAACA & GTCAAGACTATTTGTTAACTC & 461 \\
\hline
\end{tabular}

Data set. In order to investigate the degree of genetic variation among the samples, sequence data were analysed in 2 ways. Haplotypes were constructed by utilising all sequence data for each gene in turn. In order to reduce background noise created by the large number of polymorphisms that were only observed in single lice, new sequences were constructed for each gene based upon those polymorphic sites that were present in $10 \%$ or more of the individuals in the entire data set. This effectively removed all potential sequencing errors, in addition to all individual and low frequency polymorphisms. Other authors (Bucklin et al. 2000) have used similar criteria to reduce the number of haplotypes for population genetic tests.

Arlequin analysis. All population genetic parameters were computed in the Arlequin program (Schneider et al. 2000). Molecular diversity was calculated as both nucleotide diversity and gene diversity, based on the complete gene sequences and default settings. Nucleotide diversity indicates the probability that 2 randomly chosen homologous nucleotides are different, while the gene diversity gives the probability that 2 randomly chosen haplotypes are different in a population. Haplotype frequencies within each gene were also estimated, but only data from the analysis based on the $10 \%$ selection criteria are presented for simplicity.

Genetic differentiation between populations was estimated using analysis of molecular variance (AMOVA), in addition to pairwise population comparisons $\left(F_{\mathrm{ST}}\right)$. AMOVA describes the distribution of mtDNA variation within and among populations. Both analyses were performed for each gene using haplotype frequencies only (conventional F-statistics), since the sequences were too divergent for genetic distance correction. Transition versus transversion was accounted for, and the significance was set at $5 \%$ using 10000 permutations. The significance level for $\mathrm{p}$-values was adjusted with the Bonferroni correction where appropriate (Rice 1989).

Tajima's D-test (Tajima 1989) and Fu's Fs-test (Fu 1997) were applied to test the neutral mutation hypothesis, and to test for a population expansion. In both cases significance was assessed by 1000 simulated samples under the hypothesis of selective neutrality and population equilibrium, as implemented in Arlequin. Significance of Tajima's $D$-test was based on an approximation of the beta distribution (Mes 2003).

\section{RESULTS}

\section{Polymorphisms}

The mitochondrial genes COI, A6, Cyt $b$ and 16S rRNA of Lepeophtheirus salmonis displayed extremely high levels of polymorphisms (Table 2). Within the 180 lice the highest proportion of polymorphic sites was observed in $A 6$, followed by COI, in $C y t b$ and $16 \mathrm{~S}$ rRNA. This high number of polymorphisms produced a significant number of haplotypes. Many of the polymorphisms were only present in 1 individual, and generally, few polymorphisms were particularly frequent. In the 3 protein-coding genes, some polymorphisms also resulted in amino acid changes (Table 2).

Table 2. Lepeophtheirus salmonis. Description of the total variation, the number of polymorphisms and the number of haplotypes found in COI, 16S rRNA, $A 6$ and $C y t b$ when analysing the data using the whole gene sequence

\begin{tabular}{|lccccccc|}
\hline Gene & $\begin{array}{c}\text { Length } \\
(\mathrm{bp})\end{array}$ & $\begin{array}{c}\text { Intraspecific } \\
\text { variation (\%) }\end{array}$ & $\begin{array}{c}\text { Number of } \\
\text { polymorphisms }\end{array}$ & $\begin{array}{c}\text { Amino } \\
\text { acid changes }\end{array}$ & $\begin{array}{c}\text { Total number } \\
\text { of haplotypes }\end{array}$ & $\begin{array}{c}\text { Mean nucleotide } \\
\text { diversity }\end{array}$ & $\begin{array}{c}\text { Mean gene } \\
\text { diversity }\end{array}$ \\
\hline A6 & 651 & 17.5 & 114 & 29 & 133 & 0.0085 & 0.992 \\
COI & 1536 & 15.9 & 245 & 26 & 164 & 0.0075 & 0.997 \\
16S rRNA & 1070 & 10.6 & 113 & - & 118 & 0.0028 & 0.985 \\
Cyt $b$ & 1170 & 14.4 & 169 & 43 & 158 & 0.997 \\
\hline
\end{tabular}


In the Japanese sample only $710 \mathrm{bp}$ of COI were sequenced from 17 lice (10 polymorphisms), $990 \mathrm{bp}$ of $C y t b$ were sequenced from 19 lice (48 polymorphisms), $638 \mathrm{bp}$ of $A 6$ were sequenced from 11 lice (16 polymorphisms) while $549 \mathrm{bp}$ of $16 \mathrm{~S}$ rRNA were sequenced from 9 lice (5 polymorphisms). The reason for this small number of sequences was most likely due to large sequence diversity in the primer-binding site, between the Japanese and Atlantic samples. Although the Japanese sequences were shorter, when included in a DNA alignment, they were clearly distinct from the 6 Atlantic samples. Still, due to the small number of lice amplified from Japan, and the fact that these were only sequenced for a restricted part of each gene, this sample was excluded from the remaining analyses.

\section{Molecular diversity}

Nucleotide diversity was very low within the mitochondrial genes $A 6, C O I, 16 \mathrm{~S}$ rRNA and $C y t b$ of Lepeophtheirus salmonis (Table 2). The high number of polymorphisms present in only 1 individual might explain this. The lowest mean diversity $(0.0028)$ was present in 16S rRNA, with the lowest value found within the Canadian sample. In contrast, the highest diversity was seen in $A 6$ (Table 2), and within this gene the Øst-Agder sample displayed the highest value (0.010).

Subsequently the gene diversity was high within the 4 mitochondrial genes (Table 2), and a value of 1.0 was seen in many cases. This is in agreement with the high number of haplotypes present.

\section{Tests of neutral evolution}

Due to high intraspecific variation both Tajima's $D$ and Fu's Fs-test were applied to the complete gene sequences for COI, 16S rRNA, $A 6$ and $C y t b$ to assess if there was evidence of population growth and negative selection. The result from Fu's Fs-test showed large negative values, highly significant within all 4 genes and in all 6 samples $\left(F_{S}=-14.12\right.$ to -26.84 , p < 0.030), indicative of a population expansion. The only insignificant value was found in the Canadian sample for COI ( $F S=-8.46, \mathrm{p}=0.234)$. Moreover, significant departure from selective neutrality was found in all 4 genes using Tajima's $D$-statistics ( $D=-1.73$ to $-2.64, \mathrm{p} \leq 0.032)$.

\section{Haplotype distribution and population differentiation}

The high degree of polymorphisms in the samples created a high number of haplotypes, the majority of which were individual specific (Table 2). However, the number of haplotypes was effectively reduced by constructing new sequences, from only those sites displaying polymorphism in $>10 \%$ of the individuals in the entire data set (Table 3). A high genetic variation was still present, with the majority of private haplotypes found in COI followed by A6, Cyt $b$ and $16 \mathrm{~S}$ rRNA, but several haplotypes were also shared between locations within each gene (Table 3 ).

In order to investigate the population genetic structure of Lepeophtheirus salmonis several phylogenetic analyses were performed in PAUP. However, all methods resulted in star-like trees without any resolution, due to high intraspecific variation. AMOVA, which is based on haplotype frequencies, was therefore performed to infer the $L$. salmonis population genetic structure. The results of AMOVA demonstrated that almost all genetic variation was found within, as opposed to between samples (Table 4). This was observed within all 4 genes, and confirmed by the 2 described methods. Results from the AMOVA analysis were supported by the low and mostly insignificant $F_{\mathrm{ST}}$ values for overall population differentiation (Table 4). The only significant $F_{\mathrm{ST}}$ values for overall genetic structuring were observed for the $C y t b$ and COIgenes when whole gene sequences were analysed (Table 4).

Pairwise $F_{\mathrm{ST}}$ values were computed among the samples for the 2 methods of analysis. When pairwise $F_{\mathrm{ST}}$ values were calculated based upon whole sequences for each gene independently, several significant values were detected. In Cyt $b$ a significant difference was observed between Sogn og Fjordane and Canada $\left(F_{\mathrm{ST}}=0.01264, \mathrm{p}=0.001\right)$ and Scotland and Canada $\left(F_{\mathrm{ST}}=0.00928, \mathrm{p}=0.006\right)$. Lice from Scotland and Canada were also different based on analysis of $A 6$ $\left(F_{\mathrm{ST}}=0.00924, \mathrm{p}=0.014\right)$. In COI the Canadian sample was different from all the other samples: Finmark $\left(F_{\mathrm{ST}}=0.01034, \mathrm{p}=0.003\right)$, Sogn og Fjordane $\left(F_{\mathrm{ST}}=0.01034, \mathrm{p}=0.003\right), \varnothing \mathrm{st}-\operatorname{Agder}\left(F_{\mathrm{ST}}=0.00920\right.$, $\mathrm{p}=0.007)$, Scotland $\left(F_{\mathrm{ST}}=0.01034, \mathrm{p}=0.003\right)$ and Russia $\left(F_{\mathrm{ST}}=0.00920, \mathrm{p}=0.007\right)$. After Bonferroni correction for multiple independent tests (adjusted $\mathrm{p}=0.003$ ), some of the above differences were no longer significant. However, differences between the sample collected in Canada and several other samples (Sogn og Fjordane, Finmark and Scotland) remained significant. No significant differences between any of the other samples were detected, either before or after Bonferroni correction.

Most pairwise sample comparisons based upon the $10 \%$ selection criteria revealed low and insignificant $F_{\mathrm{ST}}$ values. However, a significant p-value was observed in $C y t b$. In this case there was a significant difference between the samples from Sogn og Fjordane and Canada $\left(F_{\mathrm{ST}}=0.04611, \mathrm{p}=0.023\right)$, and between Øst-Agder and Russia $\left(F_{\mathrm{ST}}=0.04046, \mathrm{p}=0.042\right)$. After 
Table 3. Lepeophtheirus salmonis. Distribution of haplotypes (actual numbers) constructed from sequences based upon selecting only polymorphic sites with frequency $\geq 10 \%$ in the total population, for COI, 16S rRNA, $A 6$ and Cyt $b$ in the 6 samples investigated. F = Finmark, $\mathrm{SF}=$ Sogn og Fjordane, $\mathrm{A}=$ Øst-Agder, $\mathrm{S}=$ Scotland $, \mathrm{C}=\mathrm{Canada}, \mathrm{R}=$ Russia. H: haplotypes defined for each gene separately

\begin{tabular}{|c|c|c|c|c|c|c|c|c|c|c|c|c|c|c|c|c|c|c|c|c|c|c|c|c|}
\hline \multirow[b]{2}{*}{$\mathrm{H}$} & \multirow[b]{2}{*}{$\mathrm{F}$} & \multirow{2}{*}{\multicolumn{5}{|c|}{$A 6-$}} & \multicolumn{6}{|c|}{$\mathrm{COI}$} & \multicolumn{6}{|c|}{ 16S rRNA } & \multicolumn{6}{|c|}{$C_{V t} b$} \\
\hline & & & & & & & $\mathrm{F}$ & $\mathrm{SF}$ & A & $\mathrm{s}$ & $\mathrm{C}$ & $\mathrm{R}$ & $\mathrm{F}$ & $\mathrm{SF}$ & A & $\mathrm{S}$ & $\mathrm{C}$ & $\mathrm{R}$ & $\mathrm{F}$ & $\mathrm{SF}$ & A & $\mathrm{S}$ & $\mathrm{C}$ & $\mathrm{R}$ \\
\hline 1 & 8 & 7 & 5 & 6 & 8 & 10 & 7 & 6 & 5 & 4 & 5 & 8 & 18 & 16 & 15 & 17 & 17 & 17 & 7 & 6 & 5 & 10 & 12 & 14 \\
\hline 2 & 1 & _- & - & - & - & - & 1 & 1 & - & - & - & - & 4 & 6 & 3 & 5 & 2 & 5 & 4 & 7 & 3 & 5 & 2 & 5 \\
\hline 3 & 4 & 6 & 3 & 2 & 1 & 2 & 2 & 5 & 1 & 5 & 1 & 4 & 3 & 2 & 3 & 1 & 4 & 2 & 3 & 4 & 3 & 4 & 1 & 2 \\
\hline 4 & 3 & - & 1 & - & 5 & 2 & 1 & - & - & - & - & - & 5 & 6 & 7 & 7 & 7 & 6 & 6 & 1 & 4 & 1 & 5 & 1 \\
\hline 5 & 1 & - & 1 & - & 1 & - & 4 & 1 & 2 & - & 5 & 1 & - & - & 1 & - & - & - & - & 2 & 5 & 2 & - & 1 \\
\hline 6 & 1 & - & - & - & - & - & 3 & - & 2 & 1 & 1 & - & - & - & 1 & - & - & - & 1 & - & - & - & 2 & - \\
\hline 7 & 2 & 2 & 2 & 5 & 2 & 1 & 1 & - & 1 & 4 & 4 & 2 & - & - & - & - & - & - & 1 & - & 1 & 2 & - & - \\
\hline 8 & 1 & - & 1 & 2 & 1 & - & - & 1 & 1 & 2 & 4 & 2 & - & - & - & - & - & - & 2 & 4 & 5 & 4 & 5 & 6 \\
\hline 9 & 1 & 3 & 2 & 3 & - & - & - & 1 & - & - & - & - & - & - & - & - & - & - & 1 & 2 & 3 & 2 & 1 & - \\
\hline 10 & 1 & - & - & 1 & 2 & 2 & 1 & 3 & 2 & 5 & - & 2 & - & - & - & - & - & - & 1 & - & - & - & - & - \\
\hline 11 & 2 & - & 1 & 1 & - & - & 2 & 4 & 5 & 1 & 4 & 6 & - & - & - & - & - & - & 1 & - & - & - & - & - \\
\hline 12 & 4 & 4 & 4 & 2 & 3 & 3 & 1 & - & - & - & - & - & - & - & - & - & - & - & 1 & - & - & - & - & - \\
\hline 13 & 1 & 1 & 2 & - & - & - & 1 & - & - & - & - & - & - & - & - & - & - & - & - & 1 & - & 1 & - & - \\
\hline 14 & - & 1 & 1 & - & - & - & 1 & 1 & 3 & 1 & 1 & - & - & - & - & - & - & - & - & - & 1 & - & - & - \\
\hline 15 & - & 1 & - & - & - & 2 & - & 1 & 1 & 1 & - & - & - & - & - & - & - & - & - & - & 1 & - & - & - \\
\hline 16 & - & 1 & 2 & 1 & - & - & - & 1 & - & - & - & - & - & - & - & - & - & - & - & - & 1 & - & - & - \\
\hline 17 & - & 1 & - & 1 & - & - & - & 1 & - & - & - & - & - & - & - & - & - & - & - & - & 1 & - & - & - \\
\hline 18 & - & 1 & - & - & - & - & - & - & 1 & 2 & - & 1 & - & - & - & - & - & - & - & - & - & 1 & - & - \\
\hline 19 & - & 1 & 1 & 1 & - & 1 & - & - & 1 & - & - & - & - & - & - & - & - & - & - & - & - & - & 2 & - \\
\hline 20 & - & 1 & 1 & - & - & - & - & - & 1 & - & - & - & - & - & - & - & - & - & - & - & - & - & - & 1 \\
\hline 21 & - & - & 1 & - & 1 & - & - & 1 & - & - & 2 & 1 & - & - & - & - & - & - & - & - & - & - & - & - \\
\hline 22 & - & - & 1 & - & - & 1 & - & 1 & - & - & - & - & - & - & - & - & - & - & - & - & - & - & - & - \\
\hline 23 & - & - & 1 & - & - & - & - & 1 & - & - & - & - & - & - & - & - & - & - & - & - & - & - & - & - \\
\hline 24 & - & - & - & 1 & - & - & - & 1 & - & - & - & - & - & - & - & - & - & - & - & - & - & - & - & - \\
\hline 25 & - & - & - & 1 & 1 & - & - & - & 1 & - & - & - & - & - & - & - & - & - & - & - & - & - & - & - \\
\hline 26 & - & - & - & 1 & - & - & - & - & 1 & - & - & - & - & - & - & - & - & - & - & - & - & - & - & - \\
\hline 27 & - & - & - & 1 & - & 1 & - & - & 1 & - & - & - & - & - & - & - & - & - & - & - & - & - & - & - \\
\hline 28 & - & - & - & 1 & - & - & - & - & 1 & - & - & - & - & - & - & - & - & - & - & - & - & - & - & - \\
\hline 29 & - & - & - & - & 2 & - & - & - & - & 1 & - & - & - & - & - & - & - & - & - & - & - & - & - & - \\
\hline 30 & - & - & - & - & 2 & - & - & - & - & 1 & - & 1 & - & - & - & - & - & - & - & - & - & - & - & - \\
\hline 31 & - & - & - & - & 1 & - & - & - & - & 1 & - & - & - & - & - & - & - & - & - & - & - & _ & - & - \\
\hline 32 & - & - & - & - & - & 1 & - & - & - & 1 & - & 2 & - & - & - & - & - & - & - & _ & - & - & - & - \\
\hline 33 & - & - & - & - & - & 1 & - & - & - & 1 & - & - & - & - & - & - & - & - & - & - & - & - & - & - \\
\hline 34 & - & - & - & - & - & 1 & - & - & - & - & 1 & - & - & - & - & - & - & - & - & - & - & - & - & - \\
\hline 35 & 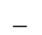 & - & - & _ & - & 1 & - & - & - & - & 1 & _- & - & _ & _ & - & - & - & - & _ & - & _ & - & - \\
\hline 36 & - & - & - & - & - & 1 & - & - & - & & 2 & - & - & - & - & - & - & - & - & _ & - & - & - & - \\
\hline 37 & - & - & - & - & - & - & - & - & - & - & - & 1 & - & - & - & - & - & - & - & - & - & - & - & - \\
\hline 38 & - & - & - & - & - & - & - & - & - & 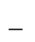 & - & 1 & - & - & - & - & - & - & - & - & - & - & - & - \\
\hline 39 & - & - & - & - & - & - & - & - & - & - & - & 1 & - & - & - & - & - & - & - & _ & - & - & - & - \\
\hline
\end{tabular}

Bonferroni correction, neither of these 2 differences was significant (adjusted $\mathrm{p}=0.05 / 15=0.003$ ). Similar results were also obtained when the haplotypes were constructed from polymorphisms with a frequency of 5 and $15 \%$ in the entire data set (data not shown).

\section{DISCUSSION}

\section{Population structure}

In order to study the population genetic structure of Lepeophtheirus salmonis in the North Atlantic, sequence variation in the mitochondrial genes $C O I, 16 \mathrm{~S}$ rRNA, $A 6$ and $C y t b$ was analysed in samples of lice collected from 7 locations. Data from the present study indicate that within the Atlantic, there is little evidence to suggest that L. salmonis is divided into discrete populations. Only the Canadian sample showed some indication of differentiation from the samples collected from the Northeast Atlantic.

To demonstrate that the 4 mitochondrial genes were suited for differentiating distinct populations, Lepeophtheirus salmonis sampled from wild chum salmon Oncorhynchus keta in the Pacific Ocean (Ishikari, Japan) was included. The Japanese lice contained several highly specific polymorphisms clearly indicating that this sample was distinct from the Atlantic samples when all 4 
mitochondrial genes were aligned (data not shown). This may reflect restricted gene flow between $L$. salmonis in the Pacific Ocean and the North Atlantic, as expected, or possibly reflect adaptation of the lice to the different hosts (see Nagasawa 2004). However, due to the high level of sequence divergence observed between the Japanese lice and lice from the North Atlantic, the majority of the lice from Japan required individual specific primers for amplification and sequencing. Consequently, it became impractical to obtain sequences from all of the Japanese lice in this study, and this sample was therefore removed from the main analysis.

Gene flow between the different Lepeophtheirus salmonis sampling locations can be an important factor explaining the lack of differentiation. Considering the fact that the 3 free-living stages of the L. salmonis life cycle can last up to $13 \mathrm{~d}$ at $10^{\circ} \mathrm{C}$ (Johnson \& Albright 1991a), the dispersal of the larvae through passive transport by ocean currents is expected to be wide (Schram 1993, Costelloe et al. 1996, 1998, Asplin et al. 2002, Tully \& Nolan 2002). Another factor that may add to the effect of transportation by sea currents is the contribution from wild salmonids and escaped farmed salmon, due to the migration of this host species for L. salmonis. Although some of the results may indicate that the lice sample from Canada displayed a weak

Table 4. Lepeophtheirus salmonis. Analysis of molecular variation (AMOVA) in the mitochondrial genes $A 6, C O I, 16 \mathrm{~S}$ rRNA and $C y t b$ in the North Atlantic. The analysis was performed on haplotypes constructed from entire gene sequences, and sequences based upon only including those polymorphic sites that displayed a frequency $\geq 10 \%$ in the total population

\begin{tabular}{|c|c|c|c|c|}
\hline Gene & Source of variation & Variation (\%) & $F_{\mathrm{ST}}{ }^{\mathrm{a}}$ & $\mathrm{p}$ \\
\hline \multicolumn{5}{|c|}{ The whole gene sequences } \\
\hline$A 6$ & $\begin{array}{l}\text { Among populations } \\
\text { Within populations }\end{array}$ & $\begin{array}{c}0.24 \\
99.76\end{array}$ & 0.002 & 0.14 \\
\hline COI & $\begin{array}{l}\text { Among populations } \\
\text { Within populations }\end{array}$ & $\begin{array}{c}0.37 \\
99.63\end{array}$ & 0.004 & 0.0001 \\
\hline 16S rRNA & $\begin{array}{l}\text { Among populations } \\
\text { Within populations }\end{array}$ & $\begin{array}{c}0 \\
100\end{array}$ & -0.0006 & 0.54 \\
\hline Cyt B & $\begin{array}{l}\text { Among populations } \\
\text { Within populations }\end{array}$ & $\begin{array}{c}0.37 \\
99.63\end{array}$ & 0.004 & 0.002 \\
\hline \multicolumn{5}{|c|}{$10 \%$ selection criteria } \\
\hline$A 6$ & $\begin{array}{l}\text { Among populations } \\
\text { Within populations }\end{array}$ & $\begin{array}{c}0 \\
100\end{array}$ & -0.003 & 0.70 \\
\hline COI & $\begin{array}{l}\text { Among populations } \\
\text { Within populations }\end{array}$ & $\begin{array}{c}0.34 \\
99.66\end{array}$ & 0.003 & 0.28 \\
\hline 16S rRNA & $\begin{array}{l}\text { Among populations } \\
\text { Within populations }\end{array}$ & $\begin{array}{c}0 \\
100\end{array}$ & -0.02 & 1.00 \\
\hline Cyt B & $\begin{array}{l}\text { Among populations } \\
\text { Within populations }\end{array}$ & $\begin{array}{c}0.98 \\
99.02\end{array}$ & 0.01 & 0.13 \\
\hline
\end{tabular}

degree of differentiation from the European samples, the overall results do show that salmon lice from Scotland, Russia and Canada are very similar to the 3 Norwegian samples in this study. This supports the assumption that wild salmonids contribute extensively to the gene flow in the North Atlantic (Todd et al. 2004). A study examining the distribution, migratory pattern and origin of wild salmon caught off the Faeroe Islands reported that $40 \%$ of the recaptured salmon were of Norwegian origin, while $20 \%$ originated from Scotland and Russia (Jacobsen et al. 2001, Hansen \& Jacobsen 2003). Surprisingly, salmon from Canada was also caught in this feeding area (Hansen \& Jacobsen 2003).

\section{Sequence variation}

In Lepeophtheirus salmonis, all 4 genes displayed a high number of polymorphic sites, resulting in intraspecific variation between 10.6 and $17.5 \%$ (Table 2). Although direct sequencing of PCR products and lack of replicates may lead to PCR or sequencing errors being included in this variation, experimental variation could not have been responsible for the very high level of polymorphism observed. In addition, building haplotypes from polymorphisms found only in at least $10 \%$ of the individuals removed the possibility of sequencing errors affecting the analyses. Furthermore, it is unlikely that the high level of intraspecific variation observed in the present study masked potential genetic differences among the samples taken. There are several reasons for this: (1) Data from all 4 genes, analysed in both ways described, showed the same trend. Furthermore, 16S rRNA displayed a low number of haplotypes when constructed from the new sequence based on the $10 \%$ criteria. The frequency of these haplotypes was clearly distributed evenly among all samples (Table 3). (2) The sample from the Pacific was highly different from all Atlantic samples, indicating that these genes are suitable for detecting barriers to gene flow. (3) Clear examples of population genetic differentiation has been observed in both Tigriopus californicus and Acartia tonsa, where the levels of intraspecific variation in $C O I$ and 16S rRNA were greater than observed in the present study (Edmans 2001, Caudill \& Bucklin 2004). 
High numbers of polymorphic sites have sometimes been associated with amplification of pseudogenes, and pseudogenes have been found for COI, Cyt $b$ and 16S rRNA in crustaceans (Schneider-Broussard \& Neigel 1997, Bucklin et al. 2000, Nguyen et al. 2002, Munasinghe et al. 2003). When we compare the Lepeophtheirus salmonis COI, Cyt $b$ and 16S rRNA sequences with the pseudogene sequences from other crustaceans, we find them to be extremely different from those. Moreover, we did not observe unexpected stop codons, and the possibility that the variation reflects pseudogenes from the salmon lice is therefore very low.

A possible explanation for the high level of polymorphisms in these 4 genes in Lepeophtheirus salmonis is the presence of several mtDNA copies due to biparental inheritance of mtDNA. Partial biparental inheritance occurs at low frequencies in Drosophila, bivalves and humans (Quesada et al. 1996, Ballard \& Whitlock 2004).

The high level of intraspecific variation observed within the 4 mitochondrial genes of Lepeophtheirus salmonis may also be a consequence of a large population size. The salmon farming industry has led to higher accessibility of hosts, resulting in population expansion and a large L. salmonis population size. When we tested for population expansion, all the locations, except the Canadian sample in COI, had large significant negative values, supporting the hypothesis of population growth. A further consequence of an expansion is the excess of low frequency haplotypes present within the population, as we observe in L. salmonis (Tables 2 \& 3). However, this can also be a result of some polymorphisms being mildly deleterious (Fry 1999, Fay et al. 2001). Tajima's $D$-statistics supported the assumption of a negative selection by significantly negative $D$-values in all 4 mitochondrial genes (see Fratini \& Vannini 2002, Navarro-Sabate et al. 2003, McMillen-Jackson \& Bert 2004, Zardoya et al. 2004).

Several amino acid substitutions were found within A6, Cyt b and COI of Lepeophtheirus salmonis (Table 2). A study of the human mtDNA has shown that $A 6, C y t b$ and $C O I$ have the highest number of amino acid substitutions of the 13 protein-coding mtDNA genes (Mishmar et al. 2003). In animal mitochondria, the amino acid substitution rate for the 13 protein-coding genes has been calculated by Lynch \& Jarrell (1993), who demonstrated that the mean amino acid substitution rate (per billion years) is lowest for COI (0.30) followed by $C y t b(0.49)$ and $A 6$ (0.99). A low amino acid substitution rate for $C O I$ is also confirmed in another study where this gene has been used to differentiate between phyla, order and species (Hebert et al. 2003). However, the substitution rate may vary between different taxa (Martin et al. 1992). In the present study, COI had the lowest amino acid substitution rate of the 3 genes sequenced, with only 26 amino acid changes, despite the fact that this gene had a high nucleotide substitution rate (Table 2). Closely following $C O I$ is $A 6$ with 29 amino acid changes, while $C y t b$ has the highest substitution rate with a total of 43 amino acid changes.

The amino acid substitutions found in Lepeophtheirus salmonis are dispersed throughout Cyt b, COI and A6. Hence, the substitutions are present in both conserved and variable regions of the 3 proteins, when we compare the amino acid sequences of L. salmonis with conserved domains and motifs of Drosophila yakuba. This is also in agreement with the localisation of the amino acid substitutions found in Cyt b, COI and A6 in humans (Mishmar et al. 2003)

In summary, the present study showed that the 4 mitochondrial genes (A6, COI, 16S rRNA and Cyt b) display a high degree of intraspecific variation. Little evidence of population genetic structuring was observed between the 3 Norwegian Lepeophtheirus salmonis samples, or between samples from Norway, Scotland and Russia. Similar results, using microsatellites, have recently been published (Todd et al. 2004). However, salmon lice from Canada showed a weak degree of differentiation compared to the other North Atlantic samples. Moreover, salmon lice from the Pacific Ocean (Japan) displayed a high amount of sample-specific polymorphisms suggesting that this sample was genetically distinct, probably as a result of isolation from the North Atlantic samples.

Acknowledgements. We thank all the people who have collected salmon lice for us: S. Urawa (Japan), V. Antonova (SevPINRO, Arkhangelsk, Russia), M. Fast (Canada), M. Snow (Scotland), H. Kongshaug (northern Norway), L. Hamre (western Norway) and Ø. Øines (southern Norway). We are grateful to L. Rosnes for technical assistance. We also thank F. Nilsen and P. Frost for comments on earlier drafts of this manuscript. This study was financed by SAM and the Norwegian Research Council.

\section{LITERATURE CITED}

Asplin L, Boxaspen K, Sandvik AD (2002) Lakselus - en trussel for villaksen. Havets miljø, Fisken og havet særnr. 2-2002:144-149

Ballard JWO, Whitlock MC (2004) The incomplete natural history of mitochondria. Mol Ecol 13:729-744

Berland B (1993) Salmon lice on wild salmon (Salmo salar) in western Norway. In: Boxshall GA, Defaye D (eds) Pathogens of wild and farmed fish: sea lice. Ellis Horwood, Chichester, p 179-187

Birkeland K (1996) Consequences of premature return by sea trout (Salmo trutta) infested with the salmon louse (Lepeophtheirus salmonis Kroyer): migration, growth, and mortality. Can J Fish Aquat Sci 53:2808-2813

Bjørn PA, Finstad B (2002) Salmon lice, Lepeophtheirus salmonis (Kroyer), infestation in sympatric populations of Arctic char, Salvelinus alpinus (L.), and sea trout, Salmo trutta (L.), in areas near and distant from salmon farms. ICES J Mar Sci 59:131-139 
Bjørn PA, Finstad B, Kristoffersen R (2001) Salmon lice infection of wild sea trout and Arctic char in marine and freshwaters: the effects of salmon farms. Aquac Res 32:947-962

Brandal PO, Egidius E, Romslo I (1976) Host blood: a major food component for the parasitic copepod Lepeophtheirus salmonis Krøyeri, 1838 (Crustacea, Caligidae). Norw J Zool 24:341-343

Bucklin A, Astthorsson OS, Gislason A, Allen LD, Smolenack SB, Wiebe PH (2000) Population genetic variation of Calanus finmarchicus in Icelandic waters: preliminary evidence of genetic differences between Atlantic and Arctic populations. ICES J Mar Sci 57:1592-1604

Butler JR (2002) Wild salmonids and sea louse infestations on the west coast of Scotland: sources of infection and implications for the management of marine salmon farms. Pest Manag Sci 58:595-608; discussion 622-629

Caudill CC, Bucklin A (2004) Molecular phylogeography and evolutionary history of the estuarine copepod, Acartia tonsa, on the Northwest Atlantic coast. Hydrobiologia 511:91-102

Costelloe M, Costelloe J, Roche N (1996) Planktonic dispersion of larval salmon-lice, Lepeophtheirus salmonis, associated with cultured salmon, Salmo salar, in western Ireland. J Mar Biol Assoc UK 76:141-149

Costelloe M, Costelloe J, Coghlan N, O'Donohoe G, O'Connor B (1998) Distribution of the larval stages of Lepeophtheirus salmonis in three bays on the west coast of Ireland. ICES J Mar Sci 55:181-187

Dixon BA, Shinn AP, Sommerville C (2004) Genetic characterization of populations of the ectoparasitic caligid, Lepeophtheirus salmonis (Krøyer 1837), using randomly amplified polymorphic DNA. Aquac Res 35:730-741

Edmans S (2001) Phylogeography of the intertidal copepod Tigriopus californicus reveals substantially reduced population differentiation at northern latitudes. Mol Ecol 10:1743-1750

Fay JC, Wyckoff GJ, Wu CI (2001) Positive and negative selection on the human genome. Genetics 158: 1227-1234

Fratini S, Vannini M (2002) Genetic differentiation in the mud crab Scylla serrata (Decapoda: Portunidae) within the Indian Ocean. J Exp Mar Biol Ecol 272:103-116

Fry AJ (1999) Mildly deleterious mutations in avian mitochondrial DNA: evidence from neutrality tests. Evolution 53:1617-1620

Fu YX (1997) Statistical tests of neutrality of mutations against population growth, hitchhiking and background selection. Genetics 147:915-925

Gantenbein B, Largiader CR (2003) The phylogeographic importance of the Strait of Gibraltar as a gene flow barrier in terrestrial arthropods: a case study with the scorpion Buthus occitanus as model organism. Mol Phylogenet Evol 28:119-130

Garcia-Machado E, Pempera M, Dennebouy N, Oliva-Suarez M, Mounolou JC, Monnerot M (1999) Mitochondrial genes collectively suggest the paraphyly of crustacea with respect to insecta. J Mol Evol 49:142-149

Hale LR, Singh RS (1987) Mitochondrial DNA variation and genetic structure in populations of Drosophila melanogaster. Mol Biol Evol 4:622-637

Hansen LP, Jacobsen JA (2003) Origin and migration of wild and escaped farmed Atlantic salmon, Salmo salar L., in oceanic areas north of the Faroe Islands. ICES J Mar Sci 60:110-119

Hebert PDN, Cywinska A, Ball SL, DeWaard JR (2003) Biological identifications through DNA barcodes. Proc R Soc Lond B Biol Sci 270:313-321
Holst JC, Jackobsen PJ (1998) Dødelighet hos utvandrende postsmolt av laks som følge av lakselusinfeksjon. Fiskets Gang 8:13-15

Holst JC, Nilsen F, Hodneland K, Nylund A (1993) Observations of the biology and parasites of postsmolt Atlantic salmon, Salmo salar, from the Norwegian Sea. J Fish Biol 42:962-966

Hurwood DA, Hughes JM, Bunn SE, Cleary C (2003) Population structure in the freshwater shrimp (Paratya australiensis) inferred from allozymes and mitochondrial DNA. Heredity 90:64-70

Isdal E, Nylund A, Nævdal G (1997) Genetic differences among salmon lice (Lepeophtheirus salmonis) from six Norwegian coastal sites: evidence from alloenzymes. Bull Eur Assoc Fish Pathol 17:17-22

Jacobsen JA, Gaard E (1997) Open-ocean infestation by salmon lice (Lepeophtheirus salmonis): comparison of wild and escaped farmed Atlantic salmon (Salmo salar L.). ICES J Mar Sci 54:1113-1119

Jacobsen JA, Lund RA, Hansen LP, O'Maoileidigh N (2001) Seasonal differences in the origin of Atlantic salmon (Salmo salar L.) in the Norwegian Sea based on estimates from age structures and tag recaptures. Fish Res 52:169-177

Jarman SN, Elliott NG, Nicol S, McMinn A (2002) Genetic differentiation in the Antarctic coastal krill Euphausia crystallorophias. Heredity 88:280-287

Johnson SC, Albright LJ (1991a) Development, growth, and survival of Lepeophtheirus salmonis (Copepoda, Caligidae) under laboratory conditions. J Mar Biol Assoc UK 71:425-436

Johnson SC, Albright LJ (1991b) The developmental stages of Lepeophtheirus salmonis (Krøyer, 1837) (Copepoda, Caligidae). Can J Zool 69:929-950

Johnson SC, Blaylock RB, Elphick J, Hyatt KD (1996) Disease induced by the sea louse (Lepeophtheirus salmonis) (Copepoda: Caligidae) in wild sockeye salmon (Oncorhynchus nerka) stocks of Alberni Inlet, British Colombia. Can J Fish Aquat Sci 53:2888-2897

Kabata Z (1979) Parasitic copepoda of British fishes. The Ray Society, London

Lee CE (2000) Global phylogeography of a cryptic copepod species complex and reproductive isolation between genetically proximate populations. Evolution 54:2014-2027

Lynch M, Jarrell PE (1993) A method for calibrating molecular clocks and its application to animal mitochondrial DNA. Genetics 135:1197-1208

Marshall HD, Baker AJ (1999) Colonization history of Atlantic island common chaffinches (Fringilla coelebs) revealed by mitochondrial DNA. Mol Phylogenet Evol 11:201-212.

Martin AP, Naylor GJ, Palumbi SR (1992) Rate of mitochondrial DNA evolution in sharks is slow compared with mammals. Nature 357:153-155

McGlashan DJ, Hughes JM (2000) Reconciling patterns of genetic variation with stream structure, earth history and biology in the Australian freshwater fish Craterocephalus stercusmuscarum (Atherinidae). Mol Ecol 9:1737-1751

McKibben MA, Hay DW (2004) Distributions of planktonic sea lice larvae Lepeophtheirus salmonis in the inter-tidal zone in Loch Torridon, Western Scotland in relation to salmon farm production cycles. Aquacult Res 35:742-750

McMillen-Jackson AL, Bert TM (2004) Genetic diversity in the mtDNA control region and population structure in the pink shrimp Farfantepenaeus duorarum. J Crustac Biol 24:101-109 
Mes THM (2003) Demographic expansion of parasitic nematodes of livestock based on mitochondrial DNA regions that conflict with the infinite-sites model. Mol Ecol 12:1555-1566

Mishmar D, Ruiz-Pesini E, Golik P, Macaulay V and 9 others (2003) Natural selection shaped regional mtDNA variation in humans. Proc Natl Acad Sci USA 100:171-176

Munasinghe DHN, Murphy NP, Austin CM (2003) Utility of mitochondrial DNA sequences from four gene regions for systematic studies of Australian freshwater crayfish of the genus Cherax (Decapoda: Parastacidae). J Crustac Biol 23:402-417

Mustafa A, Rankaduwa W, Campbell P (2001) Estimating the cost of sea lice to salmon aquaculture in eastern Canada. Can Vet J 42:54-56

Nagasawa K (2004) Sea lice, Lepeophtheirus salmonis and Caligus orientalis (Copepoda: Caligidae), of wild and farmed fish in sea and brackish waters of Japan and adjacent regions: a review. Zool Stud 43:173-178

Navarro-Sabate A, Aguade M, Segarra C (2003) Excess of nonsynonymous polymorphism at Acph-1 in different gene arrangements of Drosophila subobscura. Mol Biol Evol 20:1833-1843

Nguyen TTT, Murphy NP, Austin CM (2002) Amplification of multiple copies of mitochondrial Cytochrome $b$ gene fragments in the Australian freshwater crayfish, Cherax destructor Clark (Parastacidae: Decapoda). Anim Genet 33:304-308

Nolan DV, Martin SAM, Kelly Y, Glennon K, Palmer R, Smith T, McCormack GP, Powell R (2000) Development of microsatellite PCR typing methodology for the sea louse, Lepeophtheirus salmonis (Kroyer). Aquac Res 31:815-822

Nylund A, Wallace C, Hovland T (1993) The possible role of Lepeophtheirus salmonis (Krøyer) in the transmission of infectious salmon anaemia. In: Boxshall GA, Defaye D (eds) Pathogens of wild and farmed fish: sea lice. Ellis Horwood, Chichester, p 367-373

Quesada H, Skibinski DAG, Skibinski DOF (1996) Sex biased heteroplasmy and mitochondrial DNA inheritance in the mussel Mytilus galloprovincialis Lmk. Curr Genet 29:423-426

Rice WR (1989) Analyzing tables of statistical tests. Evolution 43:223-225

Saito M, Kojima S, Endo K (2000) Mitochondrial COI sequences of brachiopods: genetic code shared with protostomes and limits of utility for phylogenetic reconstruction. Mol Phylogenet Evol 15:331-344

Schneider S, Roessli D, Excoffier L (2000) Arlequin: a software for population genetics data analysis. Version 2.0., Genetics and Biometry Lab, Dept of Anthropology, University of Geneva

Schneider-Broussard R, Neigel JE (1997) A large-subunit mitochondrial ribosomal DNA sequence translocated to the nuclear genome of two stone crabs (Menippe). Mol Biol Evol 14:156-165

Schram TA (1993) Supplementary descriptions of the developmental stages of Lepeophtheirus salmonis (Krøyer,
1837) (Copepoda: Caligidae). In: Boxshall GA, Defaye D (eds) Pathogens of wild and farmed fish: sea lice. Ellis Horwood, Chichester, p 31-47

Schwenk K, Posada D, Hebert PDN (2000) Molecular systematics of European Hyalodaphnia: the role of contemporary hybridization in ancient species. Proc R Soc Lond B Biol Sci 267:1833-1842

Shearer TL, Van Oppen MJ, Romano SL, Worheide G (2002) Slow mitochondrial DNA sequence evolution in the Anthozoa (Cnidaria). Mol Ecol 11:2475-2487

Tajima F (1989) Statistical method for testing the neutral mutatin hypothesis by DNA polymorphism. Genetics 123:585-595

Tjensvoll K, Hodneland K, Nilsen F, Nylund A (2005) Genetic characterization of the mitochondrial DNA from Lepeophtheirus salmonis (Crustacea; Copepoda). A new gene organization revealed. Gene 353:218-230

Todd CD, Walker AM, Wolff $\mathrm{K}$, Northcott SJ and 5 others (1997) Genetic differentiation of populations of the copepod sea louse Lepeophtheirus salmonis (Kroyer) ectoparasitic on wild and farmed salmonids around the coasts of Scotland: evidence from RAPD markers. J Exp Mar Biol Ecol 210:251-274

Todd CM, Walker AM, Ritchie MG, Graves JA, Walker AF (2004) Population genetic differentiation of sea lice (Lepeophtheirus salmonis) parasitic on Atlantic and Pacific salmonids: analyses of microsatellite DNA variation among wild and farmed hosts. Can J Fish Aquat Sci 61:1176-1190

Tully O, Nolan DT (2002) A review of the population biology and host-parasite interactions of the sea louse Lepeophtheirus salmonis (Copepoda: Caligidae). Parasitology 124 Suppl: S165-182

Tully O, Poole WR, Whelan KF (1993) Infestation parameters for Lepeophtheirus salmonis (Krøyer) (Copepoda: Caligidae) parasitic on sea trout (Salmo trutta L.) off the west coast of Ireland during 1990 and 1991. Aquacult Fish Manag 24:545-555

Umetsu K, Iwabuchi N, Yuasa I, Saitou N, Clark PF, Boxshall G, Osawa M, Igarashi K (2002) Complete mitochondrial DNA sequence of a tadpole shrimp (Triops cancriformis) and analysis of museum samples. Electrophoresis 23: 4080-4084

White HC (1940) 'Sea lice' (Lepeophtheirus) and death of Salmon. J Fish Res Bd Can 5:172-175

Wootten R, Smith JW, Needham EA (1977) Studies on the salmon louse, Lepeophtheirus. Bull Off Int Epiz 87:521-522

Wootten R, Smith RJ, Needham EA (1982) Aspects of the biology of the parasitic copepods Lepeophteirus salmonis and Caligus elongatus on farmed salmonids, and their treatment. Proc R Soc Edinb B 81:185-197

Zardoya R, Castilho R, Grande C, Favre-Krey L, Caetano S, Marcato S, Krey G, Patarnello T (2004) Differential population structuring of two closely related fish species, the mackerel (Scomber scombrus) and the chub mackerel (Scomber japonicus), in the Mediterranean Sea. Mol Ecol 13:1785-1798

Submitted: June 6, 2005; Accepted: November 23, 2005

Proofs received from author(s): January 25, 2006
Editorial responsibility: Carey Cunningham,

Aberdeen, UK 